\title{
Employee Motivation Management Systems \& Practices and Their Perceived Roles on Employee Performance: The Case of FDRE-Metal \& Engineering Corporation (FDRE-METEC)
}

\author{
Professor D. Lalitha Rani ${ }^{1}$, Bahran Asrat ${ }^{2}$
}

\begin{abstract}
This study tried to assess the motivation management system and practices of one of the largest members of the metal and engineering sector in Ethiopia-METALS AND ENGINEERING CORPORATION (METEC). As such, it covered relevant issues including the organization's motivation policies and procedures, the implementation of motivation management system, and the role of the motivation system \& practices in the organization on increasing employee performance. In more specific terms, the study reflected on METEC's extrinsic tools (pay, benefit, job security, promotion, etc.) and intrinsic tools (advancement, work challenge, recognition, etc.) and the degree to which they effectively motivate employees for better performance. Since METEC is made up of more than a dozen different industries, the study targeted the management and workers of these industries in order to properly examine the realities of the corporation's motivation management system and practices. In doing so, the study assessed METEC's motivation policies and tools in view of their general relationship to employee performance. A mix of predominantly qualitative research with limited degree of quantitative tools research design used in this study. A purposefully selected sample of employees and management members of sample selected industries of METEC were contacted through survey questionnaires and key informant interviews respectively. The collected data has been processed and analyzed through the relevant statistical (SPSS) as well as qualitative tools in order to properly/adequately answer the research questions of the study. Based on the findings of the study, the researcher finally tried to forward feasible recommendations to help METEC address the potentially identified gaps on its motivation systems and practices.
\end{abstract}

Keywords: Motivation

\section{Introduction}

The concept of employee motivation is a multi-dimensional and inter-disciplinary term that has attracted the attention of researchers and practitioners from different disciplines such as psychology, human resource management, organizational behavior and others. Literature on work motivation has long been focused into two major approaches: the organizational economic approach, which focuses on extrinsic rewards; and the organizational behavior approach, which emphasizes intrinsic motivation (Sharma and Sharma, 2011). Hence, a milestone in the successes of an organization is to fulfill the continuous changing needs of organization and employees. As a result, heavy responsibility falls on management to develop strong relationship between them. Organizations expect employees to follow the rules and regulations, work according to the standards set for them; the employees expect good working conditions, fair pay, fair treatment, secure career, power and involvement in decisions.

On the other hand, researchers have found that, satisfied employees are highly motivated, have good work morale, and work more effectively and efficiently. Moreover, satisfied employees are more committed to continuous improvement and quality (Matzler, 2004). In contrast, demotivated employees often hold what they know and are unwilling to share their knowledge. Because organizational agility requires that employees at all levels engage in knowledge-based activities, understanding the reasons for employee dissatisfaction, their expectations and requirements and the directions to implement changes are essential for every organization ( Martensen and Gronholdt, 2001, cited in Lamessa, 2014). By doing so, organizations enhance their capabilities to meet increasingly turbulent and uncertain environmental conditions. In this discipline motivation is one of the important areas to be focused on.

The fact that motivation systems and practices are important variables in affecting employee, and thereby organizational performance is quite evident in the large scale metallurgical industry (Ying, 2004). In view of this assumption, the subject of this study, METEC, as a member of this sector is believed to be a relevant empirical base for this study. Metal and Engineering Corporation (METEC) is a government owned corporation specializing in large scale metal engineering operations including design, development, manufacturing, and installation. It is a key partner in the countryes industrial development efforts. With working experience of more than 30 years and organizational scope of above 16 industries and 105 factories, the Corporation is one of the biggest and experienced organizations in Ethiopia as well as the region (East Africa). It is headquartered in Addis Ababa with departments in different regional states of the country.

Some of the products that METEC offers include spare parts of capital goods, automotives, construction machineries, electrical/electronic equipments, ammunitions, aviation equipments, agricultural equipments and machineries (METEC Profiles, 2013).

The organization claims that such manufacturing and overhauling of commercial and military products as well as service management experience, METEC brings a wealth of expertise, professionalism and commitment into the country's industrial development. METEC also claims that its management approaches (in general) and the motivational system \& practices (in particular) have contributed a lot in achieving the above stated points. 


\section{International Journal of Science and Research (IJSR) \\ ISSN (Online): 2319-7064 \\ Index Copernicus Value (2013): 6.14 | Impact Factor (2014): 5.611}

Taking the corporation's significance in the country's industrial sector and its current expansion in to consideration, as well as supported by the personal experience with the corporation, the researcher was initiated to assess the motivational system \& practices of METEC in view of the corporation 's employee performance. As such, the study assessed the effectiveness of the motivation tools which are used by the organization in accordance with employee"s performance. Along with this, the study has also tried to demonstrate the influence of managers on the implementation of the corporation ${ }^{\text {es }}$ motivation policies. As a result, the research tried to help in identifying and reducing the barriers of intrinsic and extrinsic motivation in the organization.

Given this realities, the researcher believed that how METEC designed and handles its motivation system should be investigated. The study focused on how such approach could affect the performance of the employees as well as productivity of the corporation.

The general purpose of this study was to assess the motivational system and practices of METEC with respect to their role on the employee performance of the corporation. In more particular terms, the study was meant:

- To look in to the major policies, objectives, and principles of METEC 's employee motivation system.

- To identify the motivational tools used by the METEC.

- To assess the level of commitment and capability of METEC (its management) in implementing the motivation system (policies, objectives, and principles) at all levels of the corporation.

- To assess the perception and views of employees towards the motivation system and practices of METEC.

- To overview the general relationship between motivation and employee performance in the corporation.

\section{Research Methodology}

\subsection{Sources and Types of Data}

Primary and secondary data supplied information to this research. The former consisted of responses collected in the form of Likert Scale questionnaire from the sample selected METEC employees. Supporting interviews from concerned managers of METEC and its industries were also used to supplement the study with further information. They were crucial both at the formulation of the questionnaire and discussing the results of the findings. The secondary data consisted of METEC's Motivation Policy guides and Pay structure, promotion policies, performance management strategies, etc.

In collecting the primary data, the questionnaire was the main instrument. The researcher constructed a questionnaire that could infer past research questions about employees motivation and performance. Likert scale was used as measurement of such relationships. As stated by Mackenzie (2006), Likert scale measures the extent to which a person agrees or disagrees with the question that is commonly in the scale of 1 to 5 with the following the scale: $1=$ strongly disagree, $2=$ disagree, $3=$ neutral, $4=$ agree, and $5=$ strongly agree. As such, the researcher looked in to the perceptions and views of METEC's employees about the Employee MMS and Practices and how they have affected their performance. As such, questions focusing on Extrinsic Motivators (Pay, Working condition, Fringe Benefit, Security, and Promotion) and Intrinsic Motivators (Advancement, Recognition, Responsibility, leadership, and work challenge) were designed in the questionnaire. The questionnaire also assessed their general impact on the performance of employees of the Corporation.

\subsection{Data Analysis Procedures}

The researcher reviewed the relevant empirical documents stated above. Data collected from the questionnaire were then edited, coded and tabulated for effective analysis. The processed data then got analyzed, summarized, and interpreted accordingly with the aid of frequency distribution of responses from study participants.

The method of triangulation was used to harmonize and contrast the inputs of the data generated from secondary sources with that of interview and questionnaire generated primary data. Finally, the findings of the study were interpreted, concluded, and recommended for in view of the theories, principles, and accepted (benchmark) practices of Employee Motivation and their impacts on Performance.

\section{Research Findings}

METEC ${ }^{\text {ee }}$ S EMMS Policies \& Tools and Implementation Discussions handled in this section focus on the employee motivation policies \& tools as applied in METEC. The information presented here is derived from the interview sessions the researcher held with relevant managers at head quarters and industry (business unit) levels. In this regard, the researcher interviewed the Director of Corporate Human Resource Development \& Management Directorate (HRDMD) of METEC. The interview also included the General Managers and HRD Heads of the four selected industries (business units) of METEC. As such, the findings represent the official account of the organization on its EMMS In more specific terms, the policies, principles, system \& practices of employee motivation, and their impact on the performance of employees have been addressed.

The summary of the answers to the interview questions of the researcher is presented here under.

- To begin with FDRE-METEC associates its EMMS largely with its corporate missions \& goals, which focus on "promoting the country"s (Ethiopia) industrial development in a modern and sustainable manner." The staff and management of METEC are therefore assumed to be mobilized towards this grand mission and METEC expects its members to live up to this commitment. In this regard, the management of METEC believes that its employees are all clear with the organization 's principles, priorities and mission. To this effect, they are supposed to be updated with any changes and emergent strategies in a regular manner so that they could carry on their tasks in an efficient manner.

\section{Volume 5 Issue 1, January 2016}




\section{International Journal of Science and Research (IJSR) \\ ISSN (Online): 2319-7064}

Index Copernicus Value (2013): 6.14 | Impact Factor (2014): 5.611

- METEC has EMMS backed by policy statements, strategies, and standard procedures. METEC's official policy states that its EMMS is designed on the notion that "the most important resource which could help realize the above stated goals is the human resource" and that "this resource should be recognized and rewarded when performing effectively and efficiently." The reward and recognition encompasses many things including education and the like which is part of the corporate policy. The policy further states that the underlined principle of METEC ${ }^{\text {es }}$ s motivational policies, strategies and methods is "building enhanced employee performance in terms of efficiency, effectiveness, productivity, quality and the like".

- In this regard, METEC admits that the organization has to play a leading role in building up the motivational behavior of its employees. To this effect, the management of METEC claims that it applies various tools of motivation to enhance employee performance. The interviews held with corporate as well as industry (business unit) level management and policy documents reveal that the official stand of the organization is that factors that really motivate its employees are democratization, good governance, decentralization, and empowerment. This clearly implies that METEC's EMMS and practices are less of extrinsic nature and more of intrinsic nature.

- METEC's management tries to justify its position regarding its favourite ,motivation tools ${ }^{\text {ee }}$ by underlining two points. First, METEC argues that its organizational vision, missions, and goals make it unique in that it is established to lead the industrial transformation of the country through such moves as targeted investment in to complex metal \& engineering sectors, spear heading the construction of mega development projects (power, engineering, manufacturing, etc.), and thereby facilitating technology \& knowledge transfer to and through the local manufacturing sector. Thus, METEC's management believes that its employees are all clear with the organization "s principles, priorities and mission. The staff and management of METEC are therefore assumed to be energized by this grand/noble role of METEC rather than simplistic provisions such as pay, benefits, etc. Second, the organization's formation under the FDRE's Ministry of Defense led to a unique staff \& management composition. As such, the staff \& management of METEC come from the military as well as civil background, making the organization of a different environment from the usual ,corporate entities whose primary concern is profit making. This is viewed by METEC's management as a reason for focusing on the more intrinsic tools to motivate its members.

- Finally, METEC's management strongly believes that the existing EMMS and its application have positively influenced employee performance in general and efficiency \& effectiveness in particular.

The points stated above summarize the management/corporate view of the major issues with regards to METEC's EMMS and its role in enhancing employee performance. In this regard, the organization is learnt to be more focused on the intrinsic motivation tools while it admittedly down plays the extrinsic variables.
Employee Views on METEC's Motivation Policies \& Tools and their Impact on Employee Performance

As stated above, this section presents the analysis results and implied findings of the questionnaire generated data from employees of METEC, who were sample selected from the specified industries and its HQ. in order to maintain order, simplicity, and ease of understanding, this section is classified in to four sub-sections. As such, it starts with presenting the personal (demographic \& job related) characteristics of the sample group contacted through questionnaire (See Sub-Section 5.3.1). Then, the views and experiences of the respondents (through Likert scale questions) on the company's Extrinsic Motivation Policies \& Tools (pay, benefits, working conditions, job security, and promotion) and the way they are implemented are presented (See Sub-Section 5.3.2). This is followed by that of Intrinsic Motivation Policies \& Tools (advancement, recognition, responsibility, leadership \& supervision, and work challenge) and the way they are implemented in METEC (See Sub-Section 5.3.3). Finally, the respondents ${ }^{\text {ee }}$ views regarding the effects of their motivation levels on their performance as employees of METEC are analyzed and presented under Sub-Section 5.3.4.

Employees ${ }^{e e}$ View towards METEC ${ }^{e s}$ Extrinsic Motivation Policies \& Tools

After setting the policy and management orientations of METEC's EMMS, the study moves to analyzing and presenting the individual views of employees (of all age groups, genders, experience, qualification, specialization, and most importantly all job positions) regarding the EMMS of METEC by focusing on the tools \& approaches that the organization puts in to use. As such, the analysis starts with the ,Extrinsic Motivation Tools ${ }^{\text {ee }}$ in METEC, which is presented in the parts here under.

As already stated above, the researcher used the „Job Position $^{\text {ee }}$ of respondents to analyze the data and make sure that the views all organizational members are represented. Therefore, responses of employees (classified as „Clericale, „Professional/Expert"e, and ,Supervisor/Manager") regarding the application and effects of each of the five selected „Extrinsic Motivation Tools ${ }^{\text {ee }}$ (Pay, Benefit, Working Conditions, Job Security, and Promotion) is presented on subsequent tables below

\section{Pay}

Pay rates and related factors (increment, scales, and competitiveness) do play a significant role in determining an employee"s motivational state. Pay is an instrument in fulfilling so many needs. In economies such as ours, money generated from employment facilitates the obtaining of food, shelter, and clothing and provides the means to enjoy valued leisure interest outside of work. As many classical as well as contemporary sources indicate, factors such as Pay are powerful motivators particularly on employees of lower (clerical) positions. Moreover, pay can serve as symbol of achievement and a source of recognition. Employees often see pay as a reflection of organization. The data presented below (see Table 5.2 here under) summarizes the views of each respondent group regarding the Pay System of METEC 


\section{International Journal of Science and Research (IJSR) \\ ISSN (Online): 2319-7064 \\ Index Copernicus Value (2013): 6.14 | Impact Factor (2014): 5.611}

in terms of its effectiveness in triggering their motivational

levels.

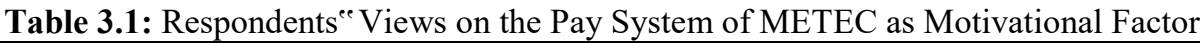

\begin{tabular}{|c|c|c|c|c|c|c|c|c|c|c|c|c|c|c|c|}
\hline \multirow{3}{*}{ ITEMS } & \multicolumn{15}{|c|}{ Respondents $^{\text {ee }}$ Views On Payment System } \\
\hline & \multicolumn{5}{|c|}{ Non-Professional/Clerical } & \multicolumn{5}{|c|}{ Professional/Expert } & \multicolumn{5}{|c|}{ Supervisor/Manager } \\
\hline & SA & A & $\mathrm{N}$ & $\mathrm{DA}$ & SDA & SA & A & $\mathrm{N}$ & $\mathrm{DA}$ & SDA & $\mathrm{SA}$ & $\mathrm{A}$ & $\mathrm{N}$ & $\mathrm{DA}$ & SDA \\
\hline \multirow{2}{*}{$\begin{array}{l}\text { The payment system is clearly } \\
\text { stated and communicated to the } \\
\text { employee }\end{array}$} & 4 & 8 & 17 & 35 & 16 & 8 & 26 & 44 & 73 & 49 & 12 & 16 & 7 & 9 & 4 \\
\hline & $5.0 \%$ & $10.0 \%$ & $21.3 \%$ & $43.8 \%$ & $20.0 \%$ & $4.0 \%$ & $13.0 \%$ & $22.0 \%$ & $36.5 \%$ & $24.5 \%$ & $25.0 \%$ & $33.3 \%$ & $14.6 \%$ & $18.8 \%$ & $8.3 \%$ \\
\hline \multirow{2}{*}{$\begin{array}{c}\text { The existing salary/pay system } \\
\text { is adequate in view of my } \\
\text { qualification and } \\
\text { accomplishment }\end{array}$} & 9 & 10 & 16 & 33 & 12 & 8 & 25 & 22 & 93 & 52 & 5 & 3 & 10 & 22 & 8 \\
\hline & $11.3 \%$ & $12.5 \%$ & $20 \%$ & $41.3 \%$ & $15 \%$ & $4 \%$ & $13 \%$ & $11 \%$ & $47 \%$ & $26 \%$ & $10.6 \%$ & $6.4 \%$ & $21.3 \%$ & $46.8 \%$ & $17 \%$ \\
\hline \multirow{2}{*}{$\begin{array}{l}\text { The magnitude of my pay is } \\
\text { similar to or exceeds that of } \\
\text { employees of other } \\
\text { organizations with similar } \\
\text { qualifications }\end{array}$} & 8 & 18 & 24 & 26 & 4 & 6 & 19 & 34 & 96 & 45 & 6 & 10 & 6 & 17 & 8 \\
\hline & $5.0 \%$ & $5.0 \%$ & $21.3 \%$ & $46.3 \%$ & $22.5 \%$ & $2.0 \%$ & $3.5 \%$ & $21.0 \%$ & $49.5 \%$ & $24.0 \%$ & $0.0 \%$ & $6.3 \%$ & $6.3 \%$ & $70.8 \%$ & $16.7 \%$ \\
\hline \multirow{2}{*}{$\begin{array}{c}\text { Employees who perform better } \\
\text { receive higher pay increase } \\
\text { than those whose performance } \\
\text { is low } \\
\end{array}$} & 5 & 13 & 26 & 29 & 7 & 4 & 29 & 60 & 81 & 26 & 3 & 4 & 15 & 16 & 10 \\
\hline & $6.3 \%$ & $16.3 \%$ & $32.5 \%$ & $36.3 \%$ & $8.8 \%$ & $2.0 \%$ & $14.5 \%$ & $30 \%$ & $40.5 \%$ & $13 \%$ & $6.4 \%$ & $8.5 \%$ & $31.9 \%$ & $34 \%$ & $21.3 \%$ \\
\hline \multirow{2}{*}{\begin{tabular}{|c|} 
The existing salary increment \\
structure is fair
\end{tabular}} & 2 & 16 & 17 & 33 & 12 & 5 & 42 & 63 & 79 & 11 & 1 & 5 & 9 & 22 & 11 \\
\hline & $2.5 \%$ & $20 \%$ & $21.3 \%$ & $41.3 \%$ & $15 \%$ & $2.5 \%$ & $21.0 \%$ & $31.5 \%$ & $39.5 \%$ & $5.5 \%$ & $2.1 \%$ & $10.6 \%$ & $19.1 \%$ & $46.8 \%$ & $23.4 \%$ \\
\hline \multirow{2}{*}{$\begin{array}{l}\text { The pay scale of our company } \\
\text { treat each employee equitably }\end{array}$} & 6 & 12 & 14 & 30 & 16 & 15 & 33 & 32 & 77 & 43 & 1 & 7 & 12 & 21 & 7 \\
\hline & $7.5 \%$ & $15.0 \%$ & $17.5 \%$ & $37.5 \%$ & $20.0 \%$ & $7.5 \%$ & $16.5 \%$ & $16.0 \%$ & $38.5 \%$ & $21.5 \%$ & $2.1 \%$ & $14.6 \%$ & $25.0 \%$ & $43.8 \%$ & $14.6 \%$ \\
\hline \multirow{2}{*}{$\begin{array}{l}\text { Bonus payment distribution is } \\
\text { fair and based on performance }\end{array}$} & 5 & 9 & 12 & 34 & 20 & 11 & 23 & 23 & 88 & 55 & 4 & 7 & 8 & 18 & 11 \\
\hline & $6.3 \%$ & $11.3 \%$ & $15.0 \%$ & $42.5 \%$ & $25.0 \%$ & $5.5 \%$ & $11.5 \%$ & $11.5 \%$ & $44.0 \%$ & $27.5 \%$ & $8.3 \%$ & $14.6 \%$ & $16.7 \%$ & $37.5 \%$ & $22.9 \%$ \\
\hline \multirow{2}{*}{$\begin{array}{c}\text { pay is an important factor in } \\
\text { motivating me for better } \\
\text { performance }\end{array}$} & 32 & 35 & 8 & 5 & 0 & 62 & 73 & 35 & 21 & 9 & 8 & 17 & 7 & 12 & 4 \\
\hline & $40.0 \%$ & $43.8 \%$ & $10.0 \%$ & $6.3 \%$ & $0.0 \%$ & $31.0 \%$ & $36.5 \%$ & $17.5 \%$ & $10.5 \%$ & $4.5 \%$ & $16.7 \%$ & $35.4 \%$ & $14.6 \%$ & $25.0 \%$ & $8.3 \%$ \\
\hline $\begin{array}{c}\text { Number of Respondents From } \\
\text { Each Job Position }\end{array}$ & \multicolumn{5}{|c|}{80} & \multicolumn{5}{|c|}{200} & \multicolumn{5}{|c|}{48} \\
\hline
\end{tabular}

The respondents reflect basically similar set of opinions on many of the aspects of METEC's Pay system. Unfortunately, respondents of all categories overwhelmingly disapprove a number of aspects of the Pay System. For example, the pay adequacy, fairness, equity, and bonus packages of METEC's Pay system are viewed skeptically or worse with outright disapproval by majority of the respondents from all job positions.

On the other aspects of the Pay System., there are results that indicate differences in views among the three respondent groups. For instance, the clerical \& professional employees have unfavourable views regarding the clarity in the design of the Pay System and the way it is communicated to employees, a view which is not shared by those who identify themselves as Supervisors/Managers. Since, such information inputs are supposed to initiate from the higher hierarchical levels and flow down to the lower levels, it is understandable why the clerical \& professional employees feel negatively regarding this practice but not the Supervisors/Managers.

On the other hand, the Supervisors/Managers were found of being similarly critical as the professionals/experts when it comes to external equity of the companyes pay and if the pay is based on performance level to which both groups expressed their disagreement. For reasons of information gap or so, the clerical employees could not clearly show their position on these issues.
Finally, the degree to which employees consider Pay as motivational factor with bearings on job related performance was assessed. The findings show that both clerical \& professional employees regard pay as a key motivational factor which significantly influences their job related performance. The Supervisors/Managers, on the other hand could not show similar tendencies towards pay as key performance factor.

From the points discussed above, some important issues are learnt. One is that the assumption set by the management of METEC regarding such factors as Pay (as motivation tools) may not be correct. The fact that all the respondent groups have expressed their common dissatisfaction on at least four of the Pay related items indicates that the official policy of METEC on such issues is not probably shared by all those concerned (for example, employees). The other important implication is that, despite the official understanding, all employees (groups) do not show uniform reaction towards all the motivation tools. The third and final implication of the assessment is that majority of the employees (clerical \& professional employees) regard Pay as key motivational variable showing that Extrinsic Motivation Tools should be given attention.

\section{Benefits}

Benefits include both monetary and non-monetary reimbursements to the employees such as pension benefits, medical benefits etc. Armstrong (2007) defines benefits as

\section{Volume 5 Issue 1, January 2016}




\section{International Journal of Science and Research (IJSR) \\ ISSN (Online): 2319-7064 \\ Index Copernicus Value (2013): 6.14 | Impact Factor (2014): 5.611}

indirect pay and includes pensions, sick pay, various types of loans, insurance, company cars and annual vacation. Most fringe benefits are tax-exempt and mutually beneficial to both the employer and especially the highly paid employee. Firms also enjoy economies of scale in providing them. More importantly, benefits can also serve as an important retention tool; pension rights as a seniority benefit serve as a deterrent since it imposes large economic costs on employees who quit early (Azasu, 2012) also identify

\begin{tabular}{|c|c|c|c|c|c|c|c|c|c|c|c|c|c|c|c|}
\hline \multicolumn{16}{|c|}{ Respondents' Views Regarding Benefits } \\
\hline \multirow{3}{*}{ ITEMS } & \multicolumn{15}{|c|}{ RESPONDENTS ${ }^{e e}$ TYPE } \\
\hline & \multicolumn{5}{|c|}{ Non-Professional/Clerical } & \multicolumn{5}{|c|}{ Non-Professional/Clerical } & \multicolumn{5}{|c|}{ Non-Professional/Clerical } \\
\hline & SA & SA & SA & SA & SA & SA & SA & SA & SA & SA & SA & SA & SA & SA & SDA \\
\hline \multirow{2}{*}{$\begin{array}{l}\text { My pension/provident fund } \\
\text { benefits are good }\end{array}$} & 3 & 4 & 10 & 36 & 27 & 8 & 19 & 22 & 93 & 55 & 8 & 10 & 9 & 14 & 7 \\
\hline & \begin{tabular}{|l|}
$3.8 \%$ \\
\end{tabular} & $5.0 \%$ & $12.5 \%$ & $45.0 \%$ & $33.8 \%$ & $4.0 \%$ & $9.5 \%$ & $11.0 \%$ & $46.5 \%$ & $27.5 \%$ & $16.7 \%$ & $20.8 \%$ & $18.8 \%$ & $29.2 \%$ & $14.6 \%$ \\
\hline \multirow{2}{*}{$\begin{array}{l}\text { The medical scheme of the } \\
\text { organization is satisfactory }\end{array}$} & 2 & 5 & 17 & 39 & 17 & 4 & 17 & 40 & 95 & 44 & 2 & 10 & 13 & 16 & 7 \\
\hline & \begin{tabular}{|l|}
$2.5 \%$ \\
\end{tabular} & $6.3 \%$ & $21.3 \%$ & $48.8 \%$ & $21.3 \%$ & $2.0 \%$ & $8.5 \%$ & $20.0 \%$ & $47.5 \%$ & $22.0 \%$ & $4.2 \%$ & $20.8 \%$ & $27.1 \%$ & $33.3 \%$ & $14.6 \%$ \\
\hline \multirow{2}{*}{$\begin{array}{l}\text { I never face problem with my } \\
\text { leave arrangement }\end{array}$} & 1 & 12 & 29 & 29 & 9 & 4 & 14 & 82 & 75 & 25 & 3 & 8 & 9 & 18 & 10 \\
\hline & \begin{tabular}{|l|}
$1.3 \%$ \\
\end{tabular} & $15.0 \%$ & $36.3 \%$ & $36.3 \%$ & $11.3 \%$ & $2.0 \%$ & $7.0 \%$ & $41.0 \%$ & $37.5 \%$ & $12.5 \%$ & $6.3 \%$ & $16.7 \%$ & $18.8 \%$ & $37.5 \%$ & $20.8 \%$ \\
\hline \multirow{2}{*}{$\begin{array}{c}\text { the organization provides me } \\
\text { with adequate Housing } \\
\text { allowance }\end{array}$} & 5 & 12 & 9 & 21 & 33 & 13 & 15 & 23 & 71 & 78 & 5 & 12 & 7 & 16 & 8 \\
\hline & \begin{tabular}{|l|}
$6.3 \%$ \\
\end{tabular} & $15.0 \%$ & $11.3 \%$ & $26.3 \%$ & $41.3 \%$ & $6.5 \%$ & $7.5 \%$ & $11.5 \%$ & $35.5 \%$ & $39.0 \%$ & $10.4 \%$ & $25.0 \%$ & $14.6 \%$ & $33.3 \%$ & $16.7 \%$ \\
\hline \multirow{2}{*}{$\begin{array}{l}\text { Transportation allowance of the } \\
\text { organization is fair }\end{array}$} & 8 & 12 & 23 & 24 & 13 & 24 & 37 & 39 & 57 & 43 & 2 & 7 & 6 & 22 & 11 \\
\hline & $10.0 \%$ & $15.0 \%$ & $28.8 \%$ & $30.0 \%$ & $16.3 \%$ & $12.0 \%$ & $18.5 \%$ & $19.5 \%$ & $28.5 \%$ & $21.5 \%$ & $2.5 \%$ & $8.8 \%$ & $7.5 \%$ & $27.5 \%$ & $13.8 \%$ \\
\hline \multirow{2}{*}{$\begin{array}{l}\text { I am provided with relevant } \\
\text { insurance packages }\end{array}$} & 0 & 4 & 18 & 11 & 47 & 10 & 14 & 42 & 82 & 52 & 12 & 18 & 7 & 6 & 5 \\
\hline & \begin{tabular}{|l|}
$0.0 \%$ \\
\end{tabular} & $5.0 \%$ & $22.5 \%$ & $13.8 \%$ & $58.8 \%$ & $5.0 \%$ & $7.0 \%$ & $21.0 \%$ & $41.0 \%$ & $26.0 \%$ & $25.0 \%$ & $37.5 \%$ & $14.6 \%$ & $12.5 \%$ & $10.4 \%$ \\
\hline \multirow{2}{*}{$\begin{array}{c}\text { Benefit Packages are important } \\
\text { motivators to me. }\end{array}$} & 26 & 41 & 11 & 2 & 0 & 65 & 87 & 26 & 17 & 5 & 5 & 12 & 15 & 9 & 5 \\
\hline & $32.5 \%$ & $51.3 \%$ & $13.8 \%$ & $2.5 \%$ & $0.0 \%$ & $32.5 \%$ & $43.5 \%$ & $13.0 \%$ & $8.5 \%$ & $2.5 \%$ & $14.6 \%$ & $25.0 \%$ & $31.3 \%$ & $18.8 \%$ & $10.4 \%$ \\
\hline $\begin{array}{l}\text { Number of Respondents From } \\
\text { Each Job Position }\end{array}$ & \multicolumn{5}{|c|}{80} & \multicolumn{5}{|c|}{200} & \multicolumn{5}{|c|}{48} \\
\hline Total Number Of Respondents & \multicolumn{15}{|c|}{328} \\
\hline
\end{tabular}

"cafeteria benefits", which entails allocating the employee a budget to spend on a menu of selected benefits. Generally speaking, benefits are supposed to be inclusive, adequate, multi-faceted, and unconditional to those employees who have met their legal/contractual requirements as employees of the organization. This part of the analysis, therefore addresses this key component of Extrinsic Motivation Tools as applied in METEC.

Table 3.2: Respondents ${ }^{\text {ee }}$ Views on the Benefit Packages of METEC as Motivational Factor

When it comes to the policies \& practices of METEC of benefit packages, the researcher found the employees ${ }^{\text {ec }}$ views as being heavily influenced by their job positions. The clerical \& professional employees have been found of strongly critical of the policies and practices of the organization on the provision of benefit packages to its members. In more specific terms these two groups have shown their disapproval at the provision of (or lack of) of four particular packages: medical coverage, pension, housing (allowance), and insurance (accident, liability, health). As the figures in Table show, at least two third of both groups felt that the provision of such packages as being inadequate, exclusive (to management members), and not competitive with that of other similar companies (in sector, size, reputation, etc.). The researcher found this perception as understandable for two reasons. One is that such provisions as medical coverage and pensions are inadequate and in fact less competitive to that of other companies while housing (allowances) and insurance are entirely unavailable to these employee groups (clerical \& professional). The interview with the concerned management members of METEC and contents of such policies of the organization affirm this position. Furthermore, most of the benefit packages seem to focus exclusively on supervisors /managers (starting from division heads or plant/factory heads). For example company vehicles and housing are provided to such members in an almost exclusive manner even to highly sought professionals/experts.
On the other hand, the supervisors /managers have reflected more dissatisfaction on the issue of annual leave (vacation). They feel that the intensity (volume) \& variety of their tasks makes the right to use one"s annual leave (vacation) almost impossible. Furthermore, since the overwhelming majority of the managers are of military background (medium \& medium high officers), they are at least implicitly expected to have the commitment to work long \& odd hours and be ready to be mobilized to challenging (remote, harsh) places.

\section{Working Condition/Environment}

Work condition/environment includes variables that ensure health and safety in the physical work environment and employees $^{\text {ee }}$ emotional/psychological experience of the workplace.

The researcher tried to assess this aspect as a potential motivator of extrinsic nature as designed \& applied in METEC ${ }^{\text {es }}$ environment. Background information (documents \& interview) shows that METEC has exerted intensive efforts and costs in order to create efficient, convenient, and safer work conditions even though the same cannot be said about the improvement in its work environment. For example, Kaizen systems have been introduced in the company at all its industries, units, and levels. The impact assessment results show improvements in work conditions. However, the real concern here is if these improvements have created/increased motivation in the minds of the employees. The assessment results are mainly 


\section{International Journal of Science and Research (IJSR) \\ ISSN (Online): 2319-7064 \\ Index Copernicus Value (2013): 6.14 | Impact Factor (2014): 5.611}

represented in the table below followed by the discussions

on their implications.

Table 3.3: Respondents ${ }^{\text {ee }}$ Views on the Working Conditions of METEC as Motivational Factor

\begin{tabular}{|c|c|c|c|c|c|c|c|c|c|c|c|c|c|c|c|}
\hline \multicolumn{16}{|c|}{ Respondents' Views Regarding Working Conditions } \\
\hline \multirow{3}{*}{ ITEMS } & \multicolumn{15}{|c|}{ RESPONDENTS TYPE } \\
\hline & \multicolumn{5}{|c|}{ Non-Professional/Clerical } & \multicolumn{5}{|c|}{ Professional/Expert } & \multicolumn{5}{|c|}{ Supervisor/Manager } \\
\hline & SA & A & $\mathrm{N}$ & $\overline{\mathrm{DA}}$ & SDA & $\overline{\mathrm{SA}}$ & A & $\mathrm{N}$ & DA & SDA & SA & $\mathrm{A}$ & $\mathrm{N}$ & DA & SDA \\
\hline \multirow{2}{*}{$\begin{array}{l}\text { My working hours are } \\
\text { reasonable }\end{array}$} & 8 & 16 & 24 & 22 & 10 & 28 & 43 & 39 & 59 & 31 & 3 & 7 & 11 & 18 & 10 \\
\hline & $10.0 \%$ & $20.0 \%$ & $30.0 \%$ & $27.5 \%$ & $12.5 \%$ & $14.0 \%$ & $21.5 \%$ & $19.5 \%$ & $29.5 \%$ & $15.5 \%$ & $6.3 \%$ & $14.6 \%$ & $22.9 \%$ & $37.5 \%$ & $20.8 \%$ \\
\hline \multirow{2}{*}{$\begin{array}{c}\text { I feel safe and protected } \\
\text { against hazards in the } \\
\text { work place }\end{array}$} & 12 & 12 & 21 & 26 & 9 & 22 & 23 & 37 & 72 & 46 & 2 & 5 & 7 & 20 & 14 \\
\hline & $15.0 \%$ & $15.0 \%$ & $26.3 \%$ & $32.5 \%$ & $11.3 \%$ & $11.0 \%$ & $11.5 \%$ & $18.5 \%$ & $36.0 \%$ & $23.0 \%$ & $4.2 \%$ & $10.4 \%$ & $14.6 \%$ & $41.7 \%$ & $29.2 \%$ \\
\hline \multirow{2}{*}{$\begin{array}{l}\text { I get the opportunity to } \\
\text { collaborate with my } \\
\text { colleagues and to } \\
\text { communicate on the } \\
\text { aspects of our work }\end{array}$} & 7 & 9 & 24 & 29 & 11 & 30 & 41 & 41 & 54 & 34 & 11 & 18 & 6 & 9 & 4 \\
\hline & $8.8 \%$ & $11.3 \%$ & $30.0 \%$ & $36.3 \%$ & $13.8 \%$ & $15.0 \%$ & $20.5 \%$ & $20.5 \%$ & $27.0 \%$ & $17.0 \%$ & $22.9 \%$ & $37.5 \%$ & $12.5 \%$ & $18.8 \%$ & $8.3 \%$ \\
\hline \multirow{2}{*}{$\begin{array}{l}\text { I feel being an active part } \\
\text { of the communication } \\
\text { flow \& decision process } \\
\text { at my work }\end{array}$} & 5 & 7 & 15 & 31 & 22 & 25 & 33 & 33 & 66 & 43 & 10 & 19 & 7 & 13 & 6 \\
\hline & $6.3 \%$ & $8.8 \%$ & $18.8 \%$ & $38.8 \%$ & $27.5 \%$ & $12.5 \%$ & $16.5 \%$ & $16.5 \%$ & $33.0 \%$ & $21.5 \%$ & $20.8 \%$ & $39.6 \%$ & $14.6 \%$ & $27.1 \%$ & $12.5 \%$ \\
\hline \multirow{2}{*}{$\begin{array}{l}\text { The arrangements of } \\
\text { office/work place is } \\
\text { convenient for employee }\end{array}$} & 3 & 7 & 22 & 31 & 17 & 4 & 21 & 42 & 86 & 47 & 3 & 4 & 6 & 27 & 8 \\
\hline & $3.80 \%$ & $8.8 \%$ & $27.5 \%$ & $38.8 \%$ & $21.3 \%$ & $2.0 \%$ & $10.5 \%$ & $21.0 \%$ & $43.0 \%$ & $23.5 \%$ & $6.3 \%$ & $8.3 \%$ & $12.5 \%$ & $56.3 \%$ & $16.7 \%$ \\
\hline \multirow{2}{*}{$\begin{array}{l}\text { good work condition \& } \\
\text { environment is an } \\
\text { important motivator to } \\
\text { me }\end{array}$} & 9 & 18 & 12 & 28 & 13 & 29 & 38 & 43 & 47 & 43 & 6 & 15 & 9 & 12 & 6 \\
\hline & $11.3 \%$ & $22.5 \%$ & $15.0 \%$ & $35.0 \%$ & $16.3 \%$ & $14.5 \%$ & $19.0 \%$ & $21.5 \%$ & $23.5 \%$ & $21.5 \%$ & $12.5 \%$ & $31.3 \%$ & $18.8 \%$ & $25.0 \%$ & $12.5 \%$ \\
\hline $\begin{array}{c}\text { NUMBER of } \\
\text { RESPONDENTS FROM } \\
\text { EACH JOB POSITION }\end{array}$ & \multicolumn{5}{|c|}{80} & \multicolumn{5}{|c|}{200} & \multicolumn{5}{|c|}{48} \\
\hline $\begin{array}{l}\text { TOTAL NUMBER OF } \\
\text { RESPONDENTS }\end{array}$ & \multicolumn{15}{|c|}{328} \\
\hline
\end{tabular}

Looking at the issues related to work conditions, the employees are primarily critical. For example, on the issues of working hours, the majority of employees (represented by clerical \& professional respondents, who make up $85 \%$ of the total number of respondents) looked to have limited reservation even though this is an area where the supervisors/managers have shown serious complaints about. The researcher learnt that working late (until evenings/nights), weekends, \& holidays is common for those at supervisory/managerial positions caused largely by successive meetings, continuous field/project assignments, and condensed number of management positions in the organization. This feeling of dissatisfaction is even compounded further due to the supervisors/managers ${ }^{\text {ee }}$ perception that those continuous field/project assignments come with huge risks on the safety \& health of one self. When it comes to the arrangement of work place, majority of all employees feel that their work places are not arranged in a convenient, efficient, \& motivating manner. This indicates that METEC should align

As far as the work environment is concerned, mixed messages are conveyed from respondents. For example, majority of the respondents feel that the company has a good practice of team work \& employee collaboration in handling things. This is a reassuring practice that must be encouraged at all levels. However, the majority of clerical \& professional employees little felt of being actively included in the communication and decision making process in relation to their work environment, a problem which obviously is not reflected by their counter parts at supervisory/managerial positions. The data from other sources indicates that this might be a result of a top-down organizational communication and decision making culture, which even management members (contacted through interview) of METEC admit as becoming a growing concern in the organization.

\section{Job Security}

The issue of job security as a motivator is not a universally adopted concept or practice. Actually, since job security is more about maintaining the status quo, many contemporary models may treat it as a hygiene factor rather than as motivator. However, it is also becoming a favourable move by organizations to hire people (mainly with clerical and expert background) only on short-term contract basis (3-6 months) with possible renewals or even par time basis. This is supposed to help the employer save huge costs in terms of benefits and other commitments. This is especially becoming very common in organizations that pay more attractive packages in the sector.

Actually, METEC adopts such an approach (3 months contract with renewal subject to performance evaluation result and relevance of the position at the time) when hiring most of its civilian staff to various expert and clerical positions. This practice, therefore, is making employees more motivated to secure their jobs and realize the access to certain benefits (pension, company loans, housing, etc.) that 


\section{International Journal of Science and Research (IJSR) ISSN (Online): 2319-7064 \\ Index Copernicus Value (2013): 6.14 | Impact Factor (2014): 5.611}

come along with the extension/renewal of employment contracts.
The assessment on this issue is made based primarily on the summary table depicted here under

Table 3.4: Respondents ${ }^{\text {ee } V i e w s ~ o n ~ t h e ~ J o b ~ S e c u r i t y ~ o f ~ M E T E C ~ a s ~ M o t i v a t i o n a l ~ F a c t o r ~}$

\begin{tabular}{|c|c|c|c|c|c|c|c|c|c|c|c|c|c|c|c|}
\hline \multicolumn{16}{|c|}{ Respondents' Views Regarding Job Security } \\
\hline \multirow{3}{*}{ ITEMS } & \multicolumn{15}{|c|}{ TYPE OF RESPONDENTS } \\
\hline & \multicolumn{5}{|c|}{ Non-Professional/Clerical } & \multicolumn{5}{|c|}{ Professional/Expert } & \multicolumn{5}{|c|}{ Supervisor/Manager } \\
\hline & $\mathrm{SA}$ & A & $\mathrm{N}$ & DA & SDA & SA & A & $\mathrm{N}$ & DA & SDA & SA & A & $\mathrm{N}$ & DA & SDA \\
\hline \multirow{2}{*}{$\begin{array}{l}\text { I am protected by insurance } \\
\text { against any accident at work }\end{array}$} & 0 & 3 & 17 & 37 & 23 & 6 & 16 & 31 & 84 & 63 & 10 & 16 & 7 & 11 & 4 \\
\hline & $0.0 \%$ & $3.8 \%$ & $21.3 \%$ & $46.3 \%$ & $28.8 \%$ & $3.0 \%$ & $8.0 \%$ & $15.5 \%$ & $42.0 \%$ & $31.5 \%$ & $20.8 \%$ & $33.3 \%$ & $14.6 \%$ & $22.9 \%$ & $8.3 \%$ \\
\hline \multirow{2}{*}{$\begin{array}{l}\text { I will not be dismissed } \\
\text { without good reason }\end{array}$} & 2 & 5 & 23 & 32 & 18 & 36 & 54 & 42 & 40 & 28 & 13 & 13 & 8 & 8 & 6 \\
\hline & $2.5 \%$ & $6.3 \%$ & $28.8 \%$ & $40.0 \%$ & $22.5 \%$ & $18.0 \%$ & $27.0 \%$ & $21.0 \%$ & $20.0 \%$ & $14.0 \%$ & $27.1 \%$ & $27.1 \%$ & $16.7 \%$ & $16.7 \%$ & $12.5 \%$ \\
\hline \multirow{2}{*}{$\begin{array}{l}\text { I am encouraged to make } \\
\text { work related decisions } \\
\text { without being afraid of } \\
\text { making mistakes. }\end{array}$} & 4 & 8 & 18 & 35 & 25 & 12 & 21 & 32 & 91 & 54 & 8 & 15 & 8 & 10 & 7 \\
\hline & $5.0 \%$ & $10.0 \%$ & $22.5 \%$ & $43.8 \%$ & $31.3 \%$ & $6.0 \%$ & $10.5 \%$ & $16.0 \%$ & $45.5 \%$ & $27.0 \%$ & $16.7 \%$ & $31.3 \%$ & $16.7 \%$ & $20.8 \%$ & $14.6 \%$ \\
\hline \multirow{2}{*}{$\begin{array}{c}\text { If I lose/damage } \\
\text { organizational resources } \\
\text { while at work, the } \\
\text { organization bears the cost }\end{array}$} & 4 & 12 & 13 & 28 & 23 & 10 & 19 & 43 & 80 & 48 & 7 & 11 & 15 & 10 & 5 \\
\hline & $5.0 \%$ & $15.0 \%$ & $16.3 \%$ & $35.0 \%$ & $28.8 \%$ & $5.0 \%$ & $9.5 \%$ & $21.5 \%$ & $40.0 \%$ & $24.0 \%$ & $14.6 \%$ & $22.9 \%$ & $31.3 \%$ & $20.8 \%$ & $10.4 \%$ \\
\hline \multirow{2}{*}{$\begin{array}{c}\text { I can express my personal } \\
\text { views without fear of losing } \\
\text { my job }\end{array}$} & 2 & 2 & 11 & 31 & 34 & 18 & 17 & 30 & 88 & 47 & 5 & 10 & 12 & 13 & 8 \\
\hline & $2.5 \%$ & $2.5 \%$ & $13.8 \%$ & $38.8 \%$ & $42.5 \%$ & $9.0 \%$ & $8.5 \%$ & $15.0 \%$ & $44.0 \%$ & $23.5 \%$ & \begin{tabular}{|l|}
$10.4 \%$ \\
\end{tabular} & $20.8 \%$ & $25.0 \%$ & $27.1 \%$ & $16.7 \%$ \\
\hline \multirow{2}{*}{$\begin{array}{l}\text { I am motivated with the } \\
\text { security and stability of } \\
\text { employment within METEC }\end{array}$} & 26 & 29 & 19 & 4 & 2 & 41 & 67 & 44 & 27 & 18 & 16 & 18 & 3 & 7 & 4 \\
\hline & $32.5 \%$ & $36.3 \%$ & $23.8 \%$ & $5.0 \%$ & $2.5 \%$ & $20.5 \%$ & $33.5 \%$ & $22.0 \%$ & $13.5 \%$ & $9.0 \%$ & $33.30 \%$ & $37.50 \%$ & $6.30 \%$ & $14.60 \%$ & $8.30 \%$ \\
\hline $\begin{array}{l}\text { Number Of Respondents } \\
\text { From Each Job Position }\end{array}$ & \multicolumn{5}{|c|}{80} & \multicolumn{5}{|c|}{200} & \multicolumn{5}{|c|}{48} \\
\hline $\begin{array}{l}\text { Total Number Of } \\
\text { Respondents }\end{array}$ & \multicolumn{15}{|c|}{328} \\
\hline
\end{tabular}

With the exception of their similarity in viewing Job Security as one of relevant motivators (majority of all the three groups identified as motivator), the results in Table 5.5 present no consistent categorical patterns of views of respondents on issues regarding the level of security they feel about their career in METEC. The three categories seem to have their opinions scattered all over the scales of agreement.

If we address the items case by case then we find for starters that both clerical \& professional employees are not provided with long term employment contracts, making this a source of career instability and replacing motivation with anticipation. On the other hand, the managers (majority of them are military officers) know that they are assigned to such positions for a longer period, which makes them feel more stable.

The views of clerical employees on the possibility of dismissal/layoff seems to have been influenced by that of the first. Probably, added with the fear that their skills are easier to get from the labour market, large number of the clerical employees (with short term contracts) occasionally feel threatened of losing their jobs at the company. This is not shared by the professionals and managers as the former expect their contracts to be routinely renewed while the later know they are there on a long term or permanent basis.
Regarding work related mistakes and related damages to property, both clerical \& professional employees picture the organization as intolerant. This is a point of concern for it has an inverse relationship to employee motivation. If employees are not encouraged to be creative/innovative even some times at the risk of making mistakes, then their motivation will be replaced by fear of consequences against their genuine efforts to improve ways of doing things. Regarding these points, the managers seem to be comfortable. The difference between the views of clerical \& professional employees vs managers may imply that the former are usually intimidated by how they are treated by their superiors while the later are not held accountable in such cases, which may make the system look arbitrary.

\section{Promotion}

Promotional opportunities have a moderate impact on job motivation. A promotion to a higher level in an organization typically involves positive changes, supervision, job content and pay. Jobs that are at the higher level of an organization usually provide employees with more freedom, more challenging work assignments and high salary. The researcher, therefore, tries to shade some light as to how the employees view the promotion system at METEC and its motivational relevance. 


\section{International Journal of Science and Research (IJSR) \\ ISSN (Online): 2319-7064 \\ Index Copernicus Value (2013): 6.14 | Impact Factor (2014): 5.611}

Table 3.5: Respondents ${ }^{\text {ec }}$ Views on the Job Promotion of METEC as Motivational Factor

\begin{tabular}{|c|c|c|c|c|c|c|c|c|c|c|c|c|c|c|c|}
\hline \multicolumn{16}{|c|}{ Respondents' Views Regarding Promotion } \\
\hline \multirow{3}{*}{ ITEMS } & \multicolumn{15}{|c|}{ TYPE OF RESPONDENTS } \\
\hline & \multicolumn{5}{|c|}{ Non-Professional/Clerical } & \multicolumn{5}{|c|}{ Professional/Expert } & \multicolumn{5}{|c|}{ Supervisor/Manager } \\
\hline & SA & A & $\mathrm{N}$ & DA & SDA & SA & A & $\mathrm{N}$ & DA & SDA & SA & A & $\mathrm{N}$ & DA & SDA \\
\hline \multirow{2}{*}{$\begin{array}{c}\text { The promotion paths are clearly } \\
\text { stated and communicated to } \\
\text { employees }\end{array}$} & 4 & 10 & 11 & 31 & 24 & 5 & 30 & 35 & 87 & 43 & 1 & 10 & 12 & 16 & 9 \\
\hline & $5.0 \%$ & $12.5 \%$ & $13.8 \%$ & $38.8 \%$ & $30.0 \%$ & $2.5 \%$ & $15.0 \%$ & $17.5 \%$ & $43.5 \%$ & $21.5 \%$ & $2.1 \%$ & $20.8 \%$ & $25.0 \%$ & $33.3 \%$ & $18.8 \%$ \\
\hline \multirow{2}{*}{$\begin{array}{c}\text { The opportunity for promotion } \\
\text { exists in this organization }\end{array}$} & 3 & 5 & 16 & 29 & 27 & 18 & 18 & 38 & 81 & 45 & 1 & 7 & 10 & 22 & 8 \\
\hline & \begin{tabular}{|l|}
$3.8 \%$ \\
\end{tabular} & $6.3 \%$ & $20.0 \%$ & $36.3 \%$ & $33.8 \%$ & $9.0 \%$ & $9.0 \%$ & $19.0 \%$ & $40.5 \%$ & $22.5 \%$ & $2.1 \%$ & $14.6 \%$ & $20.8 \%$ & $45.8 \%$ & $16.7 \%$ \\
\hline \multirow{2}{*}{$\begin{array}{l}\text { Everyone has an equal chance } \\
\text { to be promoted in the Company }\end{array}$} & 0 & 0 & 9 & 43 & 28 & 17 & 28 & 51 & 64 & 40 & 2 & 7 & 12 & 19 & 8 \\
\hline & \begin{tabular}{|l|}
$0.0 \%$ \\
\end{tabular} & $0.0 \%$ & $11.3 \%$ & $53.8 \%$ & $35.0 \%$ & \begin{tabular}{|l|}
$8.5 \%$ \\
\end{tabular} & $14.0 \%$ & $25.5 \%$ & $32.0 \%$ & $20.0 \%$ & \begin{tabular}{l|l}
$0.2 \%$ \\
\end{tabular} & $14.6 \%$ & $25.0 \%$ & $39.6 \%$ & $16.7 \%$ \\
\hline \multirow{2}{*}{$\begin{array}{l}\text { The criteria for promotion is } \\
\text { acceptable and clearly } \\
\text { communicated to employees }\end{array}$} & 2 & 5 & 15 & 39 & 19 & 15 & 23 & 55 & 59 & 48 & 4 & 4 & 14 & 20 & 6 \\
\hline & $2.5 \%$ & $6.3 \%$ & $18.8 \%$ & $48.8 \%$ & $23.8 \%$ & $7.5 \%$ & $11.5 \%$ & $27.5 \%$ & $29.5 \%$ & $24.0 \%$ & $8.3 \%$ & $8.3 \%$ & $29.2 \%$ & $41.7 \%$ & $12.5 \%$ \\
\hline \multirow{2}{*}{$\begin{array}{l}\text { Staffs are promoted in a fair } \\
\text { and transparent manner }\end{array}$} & 2 & 6 & 22 & 41 & 9 & 10 & 19 & 41 & 101 & 29 & 4 & 5 & 11 & 20 & 8 \\
\hline & $2.5 \%$ & $7.5 \%$ & $27.5 \%$ & $51.3 \%$ & $11.3 \%$ & $5.0 \%$ & $9.5 \%$ & $20.5 \%$ & $50.5 \%$ & $14.5 \%$ & \begin{tabular}{l|l}
$0.3 \%$ \\
\end{tabular} & $10.4 \%$ & $22.9 \%$ & $41.7 \%$ & $16.7 \%$ \\
\hline \multirow{2}{*}{\begin{tabular}{|c|} 
I am motivated by promotion \\
opportunities
\end{tabular}} & 31 & 37 & 7 & 3 & 3 & 78 & 67 & 38 & 11 & 6 & 12 & 19 & 13 & 3 & 1 \\
\hline & $38.8 \%$ & $46.3 \%$ & $8.8 \%$ & $3.8 \%$ & $3.8 \%$ & $39.0 \%$ & $33.5 \%$ & $19.0 \%$ & $5.5 \%$ & $3.0 \%$ & $25.0 \%$ & $39.6 \%$ & $27.1 \%$ & $6.3 \%$ & $2.1 \%$ \\
\hline $\begin{array}{l}\text { NUMBER of RESPONDENTS } \\
\text { FROM EACH JOB POSITION }\end{array}$ & \multicolumn{5}{|c|}{80} & \multicolumn{5}{|c|}{ t } & \multicolumn{5}{|c|}{48} \\
\hline $\begin{array}{l}\text { TOTAL NUMBER OF } \\
\text { RESPONDENTS } \\
\end{array}$ & \multicolumn{15}{|c|}{328} \\
\hline
\end{tabular}

In a manner that indicates the sensitive nature of employee promotion in organizations the reactions of the employees participated in this study remain extremely and similarly critical or worse disapproving of the employee promotion system \& practices of METEC. What makes it unique is that all the items used to assess the way employee promotion is applied and how it affects their motivational levels drew negative reactions from all categories (job positions).

Some of the employee views seem to be initiated by lack of awareness/information rather than due legitimate causes. For example, more than $60 \%$ of each respondent group disagreed with the statement that the "opportunity for promotion exists in this organization". This should be agreed by majority of employees because it simply is a statement of fact. Instead, it drew gross opposition from respondents. The researcher believes that this gap was created due mainly to the failure of concerned offices and superiors to properly orient employees about the scope of promotion opportunities and how to motivate oneself towards benefiting from these opportunities.

Given that the employees take promotion as an important individual motivator, such gaps could cause the organization lots of problems such as high turnover of employees because of the belief that the opportunity is not open to all.

\section{Employees' View towards METEC's Intrinsic Motivation Policies \& Tools \\ This type of motivation is self-generated. When intrinsically motivated, the individual will strive to satisfy the three innate psychological needs and is related to the job content. It occurs when people perform an activity from which they derive satisfaction from simply engaging in the activity itself. However, the organization has to present (create \& maintain) an environment that both leads to and continuously reinforces this behavior.}

For example employees with Intrinsic Motivation like to have substantial freedom to make decisions, a channel to express creativity, opportunities for advancement, recognition for good work, be treated in a polite and thoughtful manner, and possess the passion to take on tasks that are both challenging and meaningful of which feel an inherent sense of accomplishment upon successful completion.

Therefore, the researcher tried to assess the views of the employees of METEC along with the information generated from interview \& relevant policy documents of the company. Such matters as employee advancement, recognition for good work, sense of responsibility, relations with leader, and work content/challenge are the main issues assessed here.

\section{Advancement}

This motivational aspect is addressed here primarily as the initiative taken by the individual employee to seek all opportunities of learning \& development with the objective to secure personal \& career growth. As such, METEC's environment is assessed in terms its potential to create (or reinforce) motivational behavior towards personal \& career advancement. Therefore, issues such as opportunity to grow through learning new things and skills, training and development chances, jobs with great deal of day-today learning, work as the way to future success, and clear succession \& career advancement plan in the organization. 


\section{International Journal of Science and Research (IJSR) \\ ISSN (Online): 2319-7064 \\ Index Copernicus Value (2013): 6.14 | Impact Factor (2014): 5.611}

Table 3.6: Respondents ${ }^{e \mathrm{~V}}$ Views on the Personal Advancement in METEC as Motivational Factor

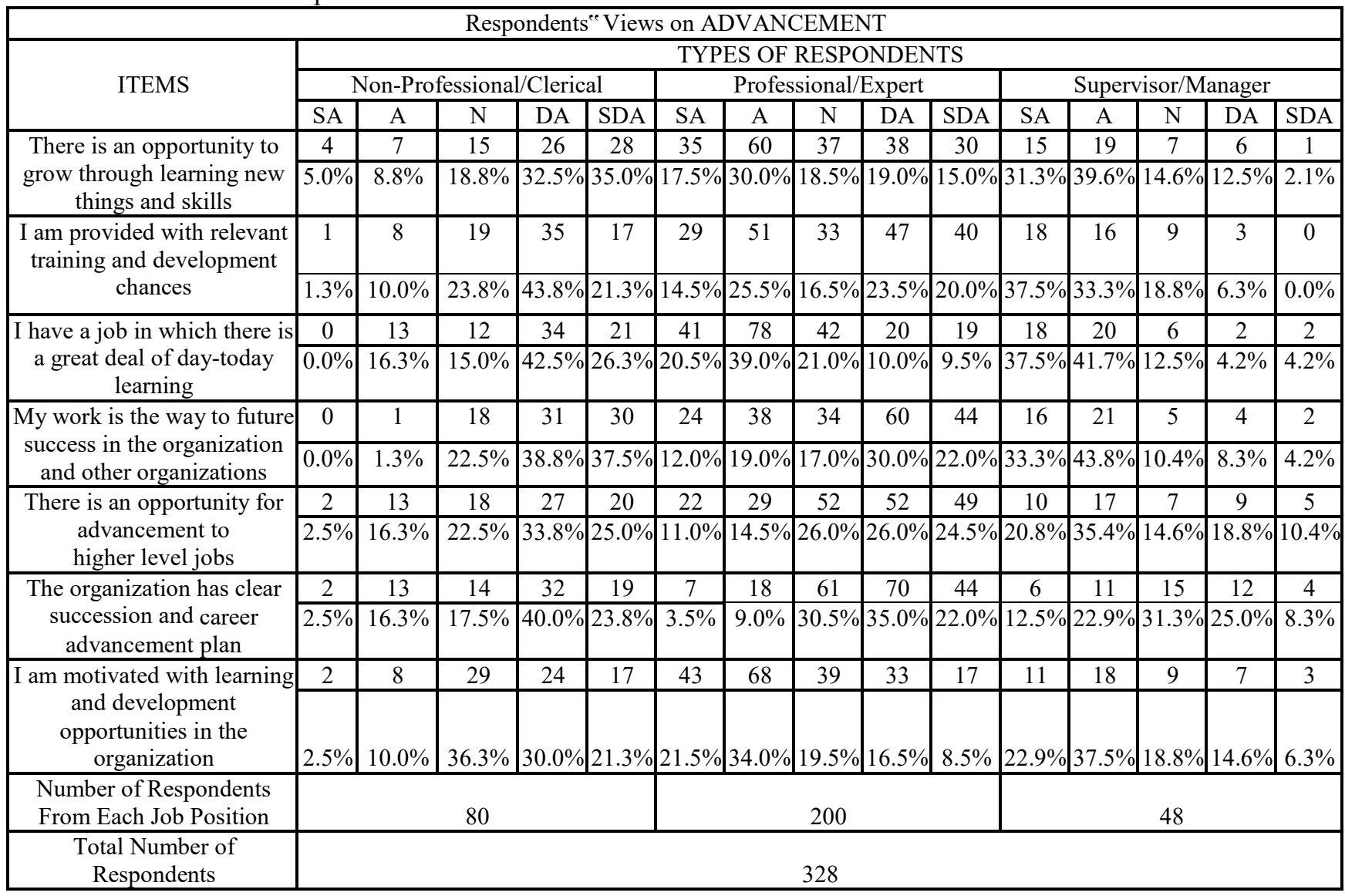

Before discussing the results presented above (See Table 5.7 above), which only represent the views of employees on how much they are motivated for advancement and if the environment at METEC reinforces this behavior, it is better to remind that the organization's motivational policy is highly focused on encouraging employees to build their intrinsic motivation. This was covered in broader terms under 5.3. Therefore, the researcher observed (from policies and management expectations of METEC) that employees (of all levels \& units) are basically supposed to have the aspiration for personal growth \& advancement. Furthermore, they are expected to value opportunities that help them realize this aspiration more than such variables as pay \& benefits. Moreover, the organization assumes that it has created a conducive environment that reinforces such behavior through intensive investment on capacity building, personal development, and research \& development. The organization, in particular, expects professionals and managers to be highly motivated \& reinforced in this regard.

According to the results of the Table above, these expectations of METEC have been found largely realistic. This is reflected in the responses of the study participants to most of the questions/items in this category. For example, those at supervisory/managerial positions have strongly advocated almost all the personal \& organizational

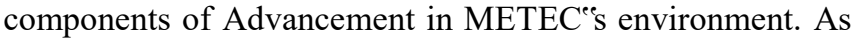
such, they have underlined Advancement as an important motivational factor. In a similar manner, they (supervisors/managers) positively regarded the environment of METEC for its opportunities to realize Advancement (personal \& career development). That is, their views regarding factors such as opportunity to grow through learning new things and skills, training and development chances, jobs with great deal of day-today learning, work as the way to future success, and clear succession \& career advancement plan in the organization have been found overwhelmingly positive.

The majority of professionals also reflected similarly favourable outlook towards part of the above listed factors as applied in METEC. After ascertaining that they indeed consider Advancement as a relevant motivational factor, these respondents have particularly been found positive towards such factors in METEC as opportunity to grow through learning new things and skills, training and development chances, and jobs with great deal of day-today learning. Majority of them (just more than half), however, showed their reservations to the other factors. They specifically showed of not being satisfied with their work as the way to future success and the level of clarity in METEC ${ }^{\text {ec }}$ s succession \& career advancement plan.

In a manner that indicates the sensitive nature of employee promotion in organizations the reactions of the employees participated in this study remain extremely and similarly critical or worse disapproving of the employee promotion system \& practices of METEC. What makes it unique is that all the items used to assess the way employee promotion is applied and how it affects their motivational levels drew negative reactions from all categories (job positions). These views have been found consistent to that of Promotion as applied in the organization. It is noted that the Professionals/experts also criticized METEC's environment 


\section{International Journal of Science and Research (IJSR) ISSN (Online): 2319-7064 \\ Index Copernicus Value (2013): 6.14 | Impact Factor (2014): 5.611}

when it comes to its openness for all employees to get promotion chances with best performance levels.

The views of clerical employees regarding Advancement tell a different story. They (significant majority of them) have shown negative reactions to all the items under this category. To begin with, more than half of such employees have implied that they do not regard Advancement as important motivator in their jobs. In a similar manner, they have disapproved the environment in METEC for realization of Advancement. In more particular terms they have expressed their strong skepticism regarding issues such as opportunity to grow through learning new things and skills, training and development chances, jobs with great deal of day-today learning, work as the way to future success, and clear succession \& career advancement plan in the organization.

The overall implication of these findings is that while METEC has done well in reinforcing the motivation of its

Table 3.7: Respondents " Views on the Personal Recognition in METEC as Motivational Factor

\begin{tabular}{|c|c|c|c|c|c|c|c|c|c|c|c|c|c|c|c|}
\hline \multicolumn{16}{|c|}{ 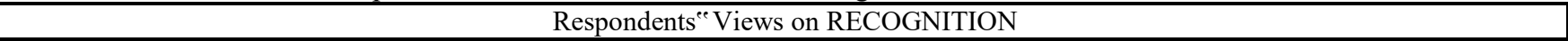 } \\
\hline \multirow{3}{*}{ ITEMS } & \multicolumn{15}{|c|}{ TYPES OF RESPONDENTS } \\
\hline & \multicolumn{5}{|c|}{ Non-Professional/Clerical } & \multicolumn{5}{|c|}{ Professional/Expert } & \multicolumn{5}{|c|}{ Supervisor/Manager } \\
\hline & SA & A & $\mathrm{N}$ & DA & SDA & SA & A & $\mathrm{N}$ & DA & SDA & SA & $\mathrm{A}$ & $\mathrm{N}$ & $\mathrm{DA}$ & SDA \\
\hline \multirow{2}{*}{$\begin{array}{l}\text { I am appreciated } \\
\text { regularly for my } \\
\text { performance }\end{array}$} & 2 & 8 & 14 & 35 & 21 & 8 & 9 & 34 & 91 & 58 & 2 & 1 & 13 & 25 & 7 \\
\hline & $2.5 \%$ & $10.0 \%$ & $17.5 \%$ & $43.8 \%$ & $26.3 \%$ & $4.0 \%$ & $4.5 \%$ & $17.0 \%$ & $45.5 \%$ & $29.0 \%$ & $4.2 \%$ & $2.1 \%$ & $27.1 \%$ & $52.1 \%$ & $14.6 \%$ \\
\hline \multirow{2}{*}{\begin{tabular}{|c|} 
I receive constructive \\
criticism about my work
\end{tabular}} & 1 & 8 & 19 & 38 & 14 & 6 & 10 & 35 & 100 & 49 & 1 & 3 & 7 & 30 & 7 \\
\hline & $1.3 \%$ & $10.0 \%$ & $23.8 \%$ & $47.5 \%$ & $17.5 \%$ & $3.0 \%$ & $5.0 \%$ & $17.5 \%$ & $50.0 \%$ & $24.5 \%$ & $2.1 \%$ & $6.3 \%$ & $14.6 \%$ & $62.5 \%$ & $14.6 \%$ \\
\hline \multirow{2}{*}{$\begin{array}{l}\text { I get credit for my } \\
\text { contribution/s to my } \\
\text { team }\end{array}$} & 2 & 11 & 25 & 25 & 17 & 6 & 20 & 50 & 70 & 54 & 4 & 7 & 5 & 24 & 8 \\
\hline & $2.5 \%$ & $13.8 \%$ & $31.3 \%$ & $31.3 \%$ & $21.3 \%$ & $3.0 \%$ & $10.0 \%$ & $25.0 \%$ & $35.0 \%$ & $27.0 \%$ & $8.3 \%$ & $14.6 \%$ & $10.4 \%$ & $50.0 \%$ & $16.7 \%$ \\
\hline \multirow{2}{*}{$\begin{array}{l}\text { I am told that I am } \\
\text { making progress }\end{array}$} & 1 & 3 & 27 & 32 & 17 & 6 & 7 & 41 & 99 & 47 & 1 & 0 & 14 & 27 & 6 \\
\hline & $1.3 \%$ & $3.8 \%$ & $33.8 \%$ & $40.0 \%$ & $21.3 \%$ & $3.0 \%$ & $3.5 \%$ & $20.5 \%$ & $49.5 \%$ & $23.5 \%$ & $2.1 \%$ & $0.0 \%$ & $29.2 \%$ & $56.3 \%$ & $12.5 \%$ \\
\hline \multirow{2}{*}{$\begin{array}{l}\text { The organization has } \\
\text { explicit policies and } \\
\text { procedures to } \\
\text { acknowledge good } \\
\text { performers }\end{array}$} & 3 & 3 & 27 & 31 & 16 & 4 & 7 & 49 & 82 & 58 & 3 & 0 & 16 & 17 & 12 \\
\hline & $3.8 \%$ & $3.8 \%$ & $33.8 \%$ & $38.8 \%$ & $20.0 \%$ & $2.0 \%$ & $3.5 \%$ & $24.5 \%$ & $41.0 \%$ & $29.0 \%$ & $6.3 \%$ & $0.0 \%$ & $33.3 \%$ & $35.4 \%$ & $25.0 \%$ \\
\hline \multirow{2}{*}{$\begin{array}{l}\text { I am motivated with } \\
\text { recognition and } \\
\text { appreciation for my } \\
\text { achievements } \\
\end{array}$} & 18 & 34 & 17 & 7 & 4 & 48 & 67 & 39 & 37 & 18 & 12 & 16 & 8 & 20 & 16 \\
\hline & $22.5 \%$ & $42.5 \%$ & $21.3 \%$ & $8.8 \%$ & $5.0 \%$ & $24.0 \%$ & $33.5 \%$ & $19.5 \%$ & $18.5 \%$ & $9.0 \%$ & \begin{tabular}{|c|}
15.0 \\
$\%$
\end{tabular} & $20.0 \%$ & $10.0 \%$ & $25.0 \%$ & $20.0 \%$ \\
\hline $\begin{array}{l}\text { Number of Respondents } \\
\text { From Each Job Position }\end{array}$ & \multicolumn{5}{|c|}{80} & \multicolumn{5}{|c|}{200} & \multicolumn{5}{|c|}{48} \\
\hline $\begin{array}{l}\text { Total Number Of } \\
\text { Respondents } \\
\end{array}$ & \multicolumn{15}{|c|}{328} \\
\hline
\end{tabular}

As presented in the table above, the points included here try to show the respondentse view regarding the culture in METEC regarding Recognition of work of employees. In order to show their impact on employee performance, the researcher specifically tried to see the views of the respondents if or not the efforts/willingness of management (at each level) to recognize (appreciate, reward, acknowledge, give credit, and give feedback) the efforts \& outcomes of employees have really motivated employees to perform better. The motivational importance of these variables to the employees is also addressed here.

The findings of the study indicate that this component of motivation is almost missing (if not seriously lacking) in METEC. This is noticeable even before referring to the professionals \& managers for Advancement, the clerical employees seem to be forgotten by the organization in this aspect.

\section{Recognition}

Recognition indicates assigning the employees with new roles and responsibilities as per their experience and willingness to perform that task. Recognition needs to be given regularly and frequently, but it also needs to be warranted and genuine. Constant recognition for trivial achievements will come across as insincere and patronizing, and will undermine the impact of true recognition.

In this regard, the researcher assessed such factors as appreciation for good performance, constructive criticism about work, giving credit for contributions, and acknowledging progress as practiced in the organization. summaries of responses of employees to the questionnaire. Information generated from interview and documents of the organization do not indicate that such practices are systematically adopted in the organization (at the corporate or industry level). This is arguably related to the very nature of the organization itself. Due to the ambitious \& national scope of missions of its establishment, METEC believes that employees should focus on the realization of the organization's objectives without expecting formal recognition for their recognition is the roles that they play in this regard.

\section{Responsibility}

Responsibility represents the motivation of employees to decide on the methods for doing the work assigned to them,

\section{Volume 5 Issue 1, January 2016}




\section{International Journal of Science and Research (IJSR) ISSN (Online): 2319-7064 \\ Index Copernicus Value (2013): 6.14 | Impact Factor (2014): 5.611}

handle the amount of work by oneself, to take part in work related decisions, and have a certain degree of authority in

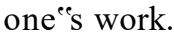

The researcher tried to assess these issues based mainly on the summary of employee responses presented here under.

Table 3.8: Respondents ${ }^{\text {ec }}$ Views on the Job Responsibility in METEC as Motivational Factor

\begin{tabular}{|c|c|c|c|c|c|c|c|c|c|c|c|c|c|c|c|}
\hline \multicolumn{16}{|c|}{ Respondents' Views Regarding to Responsibility } \\
\hline \multirow{3}{*}{ ITEMS } & \multicolumn{15}{|c|}{ TYPE OF RESPONDENTS } \\
\hline & \multicolumn{5}{|c|}{ Non-Professional/Clerical } & \multicolumn{5}{|c|}{ Professional/Expert } & \multicolumn{5}{|c|}{ Supervisor/Manager } \\
\hline & SA & A & $\mathrm{N}$ & $\mathrm{DA}$ & SDA & $\overline{\text { SA }}$ & A & $\mathrm{N}$ & DA & $\overline{\text { SDA }}$ & SA & $\mathrm{A}$ & $\mathrm{N}$ & DA & $\overline{\text { SDA }}$ \\
\hline \multirow{2}{*}{\begin{tabular}{|c|} 
I am allowed to decide on \\
the methods for doing the \\
work assigned to me
\end{tabular}} & 4 & 9 & 17 & 35 & 15 & 33 & 38 & 40 & 52 & 37 & 8 & 12 & 9 & 11 & 8 \\
\hline & $5.0 \%$ & $11.3 \%$ & $21.3 \%$ & $43.8 \%$ & $18.8 \%$ & $16.5 \%$ & $19.0 \%$ & $20.0 \%$ & $26.0 \%$ & $18.5 \%$ & $17 \%$ & $25 \%$ & $19 \%$ & $23 \%$ & $17 \%$ \\
\hline \multirow{2}{*}{$\begin{array}{l}\text { I handle the amount of } \\
\text { work I do myself }\end{array}$} & 21 & 24 & 18 & 11 & 6 & 30 & 42 & 31 & 69 & 28 & 9 & 12 & 10 & 12 & 5 \\
\hline & $26.3 \%$ & $30.0 \%$ & $22.5 \%$ & $13.8 \%$ & $7.5 \%$ & $15.0 \%$ & $21.0 \%$ & $15.5 \%$ & $34.5 \%$ & $14.0 \%$ & $18.8 \%$ & $25.0 \%$ & $20.8 \%$ & $25.0 \%$ & $10.4 \%$ \\
\hline \multirow{2}{*}{$\begin{array}{c}\text { I have the opportunity to } \\
\text { take part when decisions } \\
\text { are made }\end{array}$} & \begin{tabular}{|l|} 
\\
\end{tabular} & \begin{tabular}{|l|} 
\\
\end{tabular} & 19 & \begin{tabular}{|l|}
42 \\
\end{tabular} & 14 & 18 & 28 & 47 & \begin{tabular}{|c|} 
\\
\end{tabular} & 47 & 15 & 20 & 10 & 3 & 0 \\
\hline & $1.3 \%$ & $5.0 \%$ & $23.8 \%$ & $52.5 \%$ & $17.5 \%$ & $9.0 \%$ & $14.0 \%$ & $23.5 \%$ & $30.0 \%$ & $23.5 \%$ & $31.3 \%$ & $41.7 \%$ & $20.8 \%$ & $6.3 \%$ & $0.0 \%$ \\
\hline \multirow{2}{*}{$\begin{array}{l}\text { I have a certain degree of } \\
\text { authority in my work }\end{array}$} & 4 & 5 & 18 & 30 & 23 & 6 & 16 & 42 & 73 & 63 & 12 & 16 & 8 & 7 & 5 \\
\hline & $5.0 \%$ & $6.3 \%$ & $22.5 \%$ & $37.5 \%$ & $28.8 \%$ & $3.0 \%$ & $8.0 \%$ & $21.0 \%$ & $36.5 \%$ & $31.5 \%$ & $25.0 \%$ & $33.3 \%$ & $16.7 \%$ & $14.6 \%$ & $10.4 \%$ \\
\hline \multirow{2}{*}{$\begin{array}{l}\text { My work creates a sense } \\
\text { of responsibility to me }\end{array}$} & \begin{tabular}{|l}
10 \\
\end{tabular} & 21 & 12 & 25 & 12 & 34 & 62 & 38 & \begin{tabular}{|l|}
37 \\
\end{tabular} & 29 & $\begin{array}{l}19 \\
\end{array}$ & 25 & \begin{tabular}{|l|}
4 \\
\end{tabular} & 0 & 0 \\
\hline & $12.5 \%$ & $26.3 \%$ & $15.0 \%$ & $31.3 \%$ & $15.0 \%$ & $17 \%$ & $31 \%$ & $19 \%$ & $19 \%$ & $15 \%$ & $39.6 \%$ & $52.1 \%$ & $8.3 \%$ & $0.0 \%$ & $0.0 \%$ \\
\hline \multirow{2}{*}{$\begin{array}{l}\text { I am motivated with } \\
\text { responsibility of my job } \\
\text { within METEC }\end{array}$} & 8 & 14 & 9 & 27 & 20 & 28 & 56 & 46 & 40 & 30 & 13 & 17 & 9 & 6 & 3 \\
\hline & $10.0 \%$ & \begin{tabular}{|l}
$17.5 \%$ \\
\end{tabular} & $11.3 \%$ & $33.8 \%$ & $25.0 \%$ & $14.0 \%$ & $28.0 \%$ & $23.0 \%$ & $20.0 \%$ & $15.0 \%$ & $27.1 \%$ & $35.4 \%$ & $18.8 \%$ & $12.5 \%$ & $6.3 \%$ \\
\hline $\begin{array}{c}\text { NUMBER of } \\
\text { RESPONDENTS FROM } \\
\text { EACH JOB POSITION }\end{array}$ & \multicolumn{5}{|c|}{80} & \multicolumn{5}{|c|}{200} & \multicolumn{5}{|c|}{48} \\
\hline $\begin{array}{c}\text { TOTAL NUMBER OF } \\
\text { RESPONDENTS }\end{array}$ & \multicolumn{15}{|c|}{328} \\
\hline
\end{tabular}

We can view the components of this factor from two relevant aspects/angles: the level of motivation from the employees themselves to handle one s tasks/work in a responsible manner and the degree to which the system encourages (allows) employees to practice „Responsibility ${ }^{e c}$ in their work.

As far as the first aspect is concerned, employees of all categories (job positions) assert that they are committed to handle their work with utmost sense of responsibility. In more specific terms, majority of the employees from all positions assert that they handle their work assignments by themselves and that they feel sense of duty in their jobs.

This however is not a sentiment repeated when we look in to the other aspect of the analysis. Both the clerical \& professional employees state that the organization has not created an environment that encourages, ,responsible ${ }^{\text {ee }}$ behavior among them. They criticize the organization in what they perceive to have been limited from deciding on the methods for doing the work assigned to them, taking part in work related decisions, and have a certain degree of authority in one es work.

Due to such reasons, some of the employees seem to have been pushed to the extent of feeling little or no motivation from their work responsibilities. This is the case with the clerical employees.
The Perceived Roles of METEC's EMMS on Employee Performance

Although many factors contribute to job performance, employee motivation is viewed to be the most influential one. Work motivation along with his/her ability determines employee's level of performance. More specifically, motivation influences his/her effort toward performing the task.

An energized and highly motivated employee can reach good performance despite having some knowledge gaps. A good example for the latter situation is a new worker or trainee, who joins the organization fully motivated to work, yet lacks skills and experience. The motivation to learn and develop will quickly outweigh the weaknesses.

The effects of motivation do not stop with performance. In the group of motivated employees there are fewer work accidents, fewer rates of ethical problems, less employee turnover and lower levels of absenteeism Motivated employees feel less stress, enjoy their work, and as a result have better physical and mental health. Furthermore, motivated employees are more committed to their organizations and show less insubordination and grievance. They are also more creative, innovative, and responsive to customers, thus indirectly contributing to the long-term success of the organization. In short, motivated employees are the greatest asset of any organization.

In view of these assumptions, this part of the study tries to summarize the perceived impacts of motivation on employee performance. 


\section{International Journal of Science and Research (IJSR) \\ ISSN (Online): 2319-7064 \\ Index Copernicus Value (2013): 6.14 | Impact Factor (2014): 5.611}

Table 3.10: Respondents' Views on METEC's EMMS and Performance

The Perceived Roles of METEC ${ }^{e e}$ s EMMS on Employee Performance

\begin{tabular}{|c|c|c|c|c|c|c|c|c|c|c|c|c|c|c|c|}
\hline \multicolumn{16}{|c|}{ The Perceived Roles of METEC"es EMMS on Employee Performance } \\
\hline \multirow{3}{*}{ ITEMS } & \multicolumn{15}{|c|}{ Type of Respondents } \\
\hline & \multicolumn{5}{|c|}{ Non-Professional/Clerical } & \multicolumn{5}{|c|}{ Professional/Expert } & \multicolumn{5}{|c|}{ Supervisor/Manager } \\
\hline & SA & $\mathrm{A}$ & $\mathrm{N}$ & DA & SDA & SA & A & $\mathrm{N}$ & $\mathrm{DA}$ & SDA & SA & A & $\mathrm{N}$ & DA & SDA \\
\hline \multirow{2}{*}{$\begin{array}{c}\text { Performance based payment } \\
\text { motivated me to be } \\
\text { productive \& give quality } \\
\text { service to the organization } \\
\end{array}$} & 6 & 10 & 15 & 33 & 16 & 8 & 25 & 22 & 93 & 52 & 4 & 7 & 10 & 20 & 7 \\
\hline & $7.5 \%$ & $12.5 \%$ & \begin{tabular}{|l}
$18.8 \%$ \\
\end{tabular} & $41.3 \%$ & $20.0 \%$ & $4.0 \%$ & $12.5 \%$ & $11.0 \%$ & $46.5 \%$ & $26.0 \%$ & $8.3 \%$ & $14.6 \%$ & $20.8 \%$ & $41.7 \%$ & $14.6 \%$ \\
\hline \multirow{2}{*}{$\begin{array}{l}\text { better provision of fringe } \\
\text { benefits increased my work } \\
\text { effectiveness }\end{array}$} & 2 & 5 & 12 & 39 & 22 & 4 & 17 & 35 & 95 & 49 & 2 & 10 & 13 & 16 & 7 \\
\hline & $2.5 \%$ & $6.3 \%$ & $15.0 \%$ & $48.8 \%$ & $27.5 \%$ & $2.0 \%$ & $8.5 \%$ & $17.5 \%$ & $47.5 \%$ & $24.5 \%$ & $4.2 \%$ & $20.8 \%$ & $27.1 \%$ & $33.3 \%$ & $14.6 \%$ \\
\hline \multirow{2}{*}{\begin{tabular}{|c|}
$\begin{array}{c}\text { Improved working conditions } \\
\text { have increased my work } \\
\text { effectiveness }\end{array}$ \\
\end{tabular}} & 11 & 13 & 15 & 25 & 16 & 25 & 37 & 33 & 64 & 41 & 6 & 8 & 10 & 16 & 6 \\
\hline & $13.8 \%$ & $16.3 \%$ & $18.8 \%$ & $31.3 \%$ & $20.0 \%$ & $12.5 \%$ & $18.5 \%$ & $16.5 \%$ & $32.0 \%$ & $20.5 \%$ & $12.5 \%$ & $16.7 \%$ & $20.8 \%$ & $33.3 \%$ & $12.5 \%$ \\
\hline \multirow{3}{*}{$\begin{array}{c}\text { my feeling of being secured } \\
\text { encourages me to deliver } \\
\text { services of greater quality to } \\
\text { the organization }\end{array}$} & 2 & 5 & 23 & 32 & 18 & 36 & 54 & 42 & 40 & 28 & 13 & 13 & 8 & 8 & 6 \\
\hline & $2.5 \%$ & $6.3 \%$ & $28.8 \%$ & $40.0 \%$ & $22.5 \%$ & $18.0 \%$ & $27.0 \%$ & $21.0 \%$ & $20.0 \%$ & $14.0 \%$ & $27.1 \%$ & $27.1 \%$ & $16.7 \%$ & $16.7 \%$ & $12.5 \%$ \\
\hline & 0 & 0 & 9 & 43 & 28 & 17 & 28 & 51 & 64 & 40 & 2 & 7 & 12 & 19 & 8 \\
\hline \multirow{2}{*}{$\begin{array}{l}\text { promotion opportunities } \\
\text { inspired me to improve my } \\
\text { performance }\end{array}$} & $0.0 \%$ & $0.0 \%$ & $11.3 \%$ & $53.8 \%$ & $35.0 \%$ & $8.5 \%$ & $14.0 \%$ & $25.5 \%$ & $32.0 \%$ & $20.0 \%$ & $4.2 \%$ & $14.6 \%$ & $25.0 \%$ & $39.6 \%$ & $16.7 \%$ \\
\hline & 4 & 7 & 15 & 26 & 28 & 35 & 60 & 37 & 38 & 30 & 15 & 19 & 7 & 6 & 1 \\
\hline \multirow{2}{*}{$\begin{array}{l}\text { I believe that my career } \\
\text { advancement in METEC is } \\
\text { aligned with greater } \\
\text { accomplishment of the } \\
\text { organization }\end{array}$} & $5.0 \%$ & $8.8 \%$ & $18.8 \%$ & $32.5 \%$ & $35.0 \%$ & $17.5 \%$ & $30.0 \%$ & $18.5 \%$ & $19.0 \%$ & $15.0 \%$ & $31.3 \%$ & $39.6 \%$ & $14.6 \%$ & $12.5 \%$ & $2.1 \%$ \\
\hline & 3 & 3 & 27 & 31 & 16 & 4 & 7 & 49 & 82 & 58 & 3 & 0 & 16 & 17 & 12 \\
\hline \multirow{2}{*}{$\begin{array}{l}\text { My work accomplishments } \\
\text { are recognized by the } \\
\text { organization which } \\
\text { motivated me for further } \\
\text { improvement }\end{array}$} & $3.8 \%$ & $3.8 \%$ & $33.8 \%$ & $38.8 \%$ & $20.0 \%$ & $2.0 \%$ & $3.5 \%$ & $24.5 \%$ & $41.0 \%$ & $29.0 \%$ & $6.3 \%$ & $0.0 \%$ & $33.3 \%$ & $35.4 \%$ & $25.0 \%$ \\
\hline & 1 & 4 & 19 & 42 & 14 & 18 & 28 & 47 & 60 & 47 & 15 & 20 & 10 & 3 & 0 \\
\hline \multirow{2}{*}{$\begin{array}{c}\text { Higher responsibility in my } \\
\text { job has improved my } \\
\text { efficiency at work }\end{array}$} & $1.3 \%$ & $5.0 \%$ & $23.8 \%$ & $52.5 \%$ & \begin{tabular}{|l}
$17.5 \%$ \\
\end{tabular} & $9.0 \%$ & $14.0 \%$ & $23.5 \%$ & $30.0 \%$ & $23.5 \%$ & $31.3 \%$ & $41.7 \%$ & $20.8 \%$ & $6.3 \%$ & $0.0 \%$ \\
\hline & 5 & 7 & 13 & 33 & 22 & 22 & 40 & 33 & 65 & 40 & 8 & 13 & 12 & 9 & 5 \\
\hline \multirow{2}{*}{$\begin{array}{l}\text { the relationship with my } \\
\text { leader/s has improved my } \\
\text { performance }\end{array}$} & $6.3 \%$ & $8.8 \%$ & $16.3 \%$ & $41.3 \%$ & $27.5 \%$ & $11.0 \%$ & $20.0 \%$ & $16.5 \%$ & $32.5 \%$ & $20.0 \%$ & $16.7 \%$ & $27.1 \%$ & $25.0 \%$ & $18.8 \%$ & $10.4 \%$ \\
\hline & 4 & 11 & 20 & 37 & 8 & 24 & 47 & 51 & 40 & 38 & 15 & 12 & 11 & 7 & 3 \\
\hline \multirow{2}{*}{$\begin{array}{c}\text { the challenges I face at work } \\
\text { have inspired me towards } \\
\text { greater efficiency }\end{array}$} & $5.0 \%$ & $13.8 \%$ & $25.0 \%$ & $46.3 \%$ & $10.0 \%$ & $12.0 \%$ & $23.5 \%$ & $25.5 \%$ & $20.0 \%$ & $19.0 \%$ & $31.3 \%$ & $25.0 \%$ & $22.9 \%$ & $14.6 \%$ & $6.3 \%$ \\
\hline & 6 & 10 & 15 & 33 & 16 & 8 & 25 & 22 & 93 & 52 & 4 & 7 & 10 & 20 & 7 \\
\hline $\begin{array}{l}\text { Number Of Respondents } \\
\text { From Each Job Position }\end{array}$ & \multicolumn{5}{|c|}{80} & \multicolumn{5}{|c|}{200} & \multicolumn{5}{|c|}{48} \\
\hline $\begin{array}{l}\text { Total Number of } \\
\text { Respondents }\end{array}$ & \multicolumn{15}{|c|}{328} \\
\hline
\end{tabular}

The results in table above are consistent to the researcher's observation on the gap between management's vs employees ${ }^{\text {ee }}$ outlook of the entire EMMS in METEC and its impact on employee performance. That is, employees (particularly clerical $\&$ ) perceive that the ways adopted by METEC to improve their motivational state have either been inadequate or misplaced. Accordingly, the clerical employees could not identify a single factor from the extrinsic (five) and intrinsic (five) motivational elements that positively affected their performance.

On the other side are the supervisors/managers who have reflected better about the perceived influence of METEC's motivational tools on their job related performance. For example, they have identified benefit packages and job security from the extrinsic factors as elements that have had positive influence in their efforts to improve efficiency, quality, and effectiveness of their jobs. Their reactions have been even better when it comes to the intrinsic variables. In this aspect, the supervisors/managers have underlined all but
„Recognition ${ }^{\text {ee }}$ as factors that have had positive roles to improve their performances.

In the middle of these two extremes are the views of professionals/experts, which can at best be described as mixed. The professionals have shared the views of clerical employees on the relationship between the extrinsic factors and their job related performance. Similar to their clerical counter parts, the professionals have dismissed all but ,job security $^{\text {ee }}$ as factors which resulted in little or no improvement in their job performance. In the case of intrinsic variables, however, these employees have found METEC 's environment not only as motivating but also as performance improvement potential. Sharing the views of the supervisors/managers (except on the matter of „Responsibility"), the professionals have appreciated the state of intrinsic motivation at METEC as a factor for performance improvement. 


\section{References}

[1] Lamessa T. (2014) The Effect of Job Placement on Employee Job Satisfaction on Selected Commercial Banks in Addis Ababa. Addis Ababa University.

[2] Mackenzie, Noella and Sally Knipe (2006), "Research dilemmas: Paradigms, methods and methodology", Issues in Educational Research, Vol 16, 2006 [ Contents Vol 16. Charles Sturt University

[3] Martensen, A. \& Gronholdt, L. (2001). Using employee satisfaction measurement to improve people management: an adaptation of Kano "s quality types, Total Quality Management, 12(7), 949-957

[4] Matzler, K. and Renzl, B. (2007), “Assessing asymmetric effects in the formation of employee satisfaction", Tourism Management, Vol. 28, pp. 10931103

[5] METEC (2013) METEC Company Profiles: METEC Corporate Marketing \& Communication, Addis Ababa.

[6] Sharma, S. and Sharma, D. R. (2011). A Study of Motivational Orientation of Employees in Nationalized Banks at Agartala. Internationally Indexed \& Listed Referred e-Journal, Volume 1, Issue 6, PP. 2231-4288

[7] Ying, Z.Y. (2004) The Impact of Performance Management System on Employee performance, Analysis with WERS. 